\title{
Immigration, Ethnic Wage Differentials and Output Pay in Canada
}

\author{
Tony Fang and John S. Heywood
}

\begin{abstract}
Recent work suggests that ethnic minority wage differentials in Canada are smaller among those receiving performance pay and that the returns to performance pay are larger for ethnic minorities. This article adds to these findings. First, it demonstrates critical gender differences. The earlier findings are generated almost exclusively by males, as we show that the minority wage differential is small or zero for women in both the time rate sector and the performance pay sector. Second, accounting for immigration and language tends to move the ethnic wage differential in favour of minorities. Minority women on output pay are shown to earn more than non-minority women. While the differential often remains negative for minority men on time rates, it becomes insignificant in our most narrow comparison.
\end{abstract}

\section{Introduction}

New immigration patterns and the growing diversity of the Canadian population have generated important policy debates. At the heart of these debates are questions over the extent to which public and private institutions have responded to the changing face of Canadian society. Nowhere are these questions more apparent than in the significant barriers faced by visible minority groups in the labour market (Bloom et al. 1995; Statistics Canada 2003a). Indeed, a recent study by the Conference Board of Canada finds that visible minorities earn 14.5 per cent less than other Canadians (Conference Board of Canada 2004). This difference raises serious issues regarding constitutional rights, obstacles to economic growth and the concentration of social problems such as poverty, unemployment and social alienation. This

Tony Fang is at the School of Administrative Studies, York University and Centre for Industrial Relations and Human Resources, University of Toronto. John S. Heywood is at the Department of Economics and Graduate Program in Human Resources and Labor Relations, University of Wisconsin-Milwaukee and the Birmingham Business School, University of Birmingham. 
article employs Statistics Canada's Workplace and Employee Survey (WES) to examine the impact of ethnicity on earnings after accounting for the method of pay, minority language and immigrant status.

Fang and Heywood (2006) first examined the association between payment method and ethnic wage differentials among non-union workers in Canada. Building on earlier research, they hypothesize that output pay tying earnings to productivity makes it harder for employers to discriminate in earnings. Their estimates from the 1999 WES confirm that ethnic minorities earn significantly less than non-minorities in the time rate sector, but receive essentially identical earnings in the output pay sector. While their Canadian evidence confirms similar findings from other countries (reviewed in the next section), it does not account for the particularly high correlations in Canada between immigrant status, language skills and ethnicity. Neither does it do justice to distinctions that appear on the basis of gender (Geddes and Heywood 2003).

In this re-examination of non-union workers in Canada, we demonstrate that the reported relationship is largely absent for females. Female ethnic minorities suffer little or no discrimination in either the time rates or performance pay sectors. This reflects the associated fact that the gender earnings gap among ethnic minorities is small or zero as opposed to the large gender earnings gap among non-minorities. Moreover, incorporating immigration and language as earnings determinants tends to move ethnic wage differentials in favour of minorities. After this incorporation, the ethnic wage differential among women receiving performance pay moves modestly positive. While often remaining negative, the ethnic wage differential among men moves to zero in our most narrow comparison of occupations. Together, these examinations go towards determining the importance of ethnicity in the Canadian labour market and provide evidence on the role of payment method as a force that may limit discretionary wage setting and so influence ethnic earnings patterns.

\section{Theory and past evidence}

\section{Discrimination and Method of Pay}

According to Becker (1971), the extent of discrimination reflects the intensity of prejudice on the one hand and the cost of discrimination on the other. Payment structures linked to individual output may increase the cost of discrimination, thereby reducing its extent (Heywood and O'Halloran 2005).

Contrast two methods of setting pay. In the first, supervisors evaluate performance by judging effort or input (Lazear 1986), a process that allows a supervisor's prejudice to be translated into differences in evaluations and then into differences in earnings. Bureaucratic rules (Prendergast and Topel 1996) or concern over reputation (Baker et al. 1994) may restrict this translation but are unlikely to eliminate it. Indeed, Elvira and Town (2001) show that race influences supervisors' performance evaluations. In the 
United States, a white supervisor of both white and non-white subordinates typically gives the white a better rating than the non-white even after controlling for productivity (an objective measure of output) and demographic variables.

In the second extreme, output determines pay. The supervisor knows individual worker outputs and has a pre-established wage increment for each unit of output. Racial prejudice becomes harder to translate into differential earnings. The objective evidence increases external transparency and may create a cognitive barrier. Legal authorities judging the earnings structure are more likely to be concerned about racial earnings discrepancies between workers with identical measured productivity. Thus, the improved information on productivity generated by output-based pay increases the expected cost of discrimination by increasing the probability of detection and of the associated penalties. ${ }^{1}$

We recognize that output-based pay will not always eliminate the realm for racial and ethnicity preferences. First, output-based pay schemes often retain discretionary decisions that can influence pay such as assignment of a sales territory. Second, even if ethnicity plays no role in these assignments, there remains ex post discretion. Every piece counted must meet a quality standard, a standard that may allow supervisors scope for judgment. Nonetheless, the reduced scope for judgment and the more nearly objective productivity measures associated with output-based pay increase the cost of allowing prejudice to become differential treatment by race.

Several past studies test the association between discrimination and payment method. Gunderson (1975) uses Canadian establishment data, showing that the average gender wage difference within occupations across establishments is smaller when they use incentive pay systems. Jirjahn and Stephan (2004) find smaller gender wage differentials in Germany among those paid piece rates rather than hourly wages. In the United States, racial differentials are smaller in those industries with greater use of performance pay (Belman and Heywood 1988). On the other hand, Bronars and Moore (1995) find no role for payment methods using the 1988 to 1990 waves of the National Longitudinal Study of Youth (NLSY). Yet, Heywood and O'Halloran (2005) use the more recent waves of the NLSY (1996-2000), showing that non-white men paid time rates have earnings more than 8 per cent lower than white men paid time rates. Using the same specification, there are no racial differences in earnings among those men receiving output pay. Moreover, the premium associated with receiving output pay is twice as large for non-whites as for whites. ${ }^{2}$

Fang and Heywood (2006) use the 1999 WES to examine the determinants of the ethnic wage differential in Canada. They construct a 'non-European' ethnicity category and show that non-Europeans in Canada paid by time rates receive 6 per cent lower earnings than European Canadians, all else equal. Yet, non-European Canadians paid by output pay receive identical earnings to their European Canadian counterparts. While this result fits with much of the literature, it fails to fully explore the potential for differences by 
gender or to account for the particularly strong correlations between immigrant status, minority language usage and ethnicity.

Indeed, comparisons of the 2001 and 1991 Census from Statistics Canada indicate that nearly 80 per cent of immigrants to Canada over that period are non-Europeans (Statistics Canada 2003b). In our sample selected from the WES, the simple correlations between non-European and immigration status is 0.57 , and between non-European and minority language is 0.48 (that between minority language and immigration status is 0.58 ). These high correlations raise the possibility that the ethnic differential may simply reflect omitted variable bias and may not be the result of ethnic status, but instead be a function of immigration status or language.

\section{Immigration, Language and Earnings}

Increasingly, research focuses on the impact of the complex mixture of language, ethnic origins and immigrant status on individuals' social and economic status (Chiswick 1991, 1992; Christofides and Swidinsky 1997; Pendakur and Pendakur 1998, 2002). Lazear (1995) developed a formal model of language as human capital in which language acquisition increases individuals' trade and consumption opportunities. Increased knowledge in common language expands capacity for individuals to trade with a wider range of people. On the other hand, the costs of learning a language include the sacrifice in time, money and effort, which may result in less labour market experience or educational attainment as compared with unilinguals. This human capital theory of language has some testable implications. Since the labour market benefits of language are due to an increase in opportunities to gain from trade, the magnitude of such opportunities should be correlated with the number of people with whom the individual could speak in the same workplace or in the same community. Thus, at the margin, additional language knowledge should be associated with higher returns.

Yet minority language knowledge can present a barrier for two reasons. Lang $(1986,1993)$ suggests that language differences impose transaction costs on work interactions. One response to this transaction cost is to not hire minorities or hire them at a lower wage (Chiswick 1992; Davila et al. 1993; Dustmann 1994; Kossoudji 1988; Stolzenberg and Tienda 1997; Tienda and Neidert 1984). This can lead to segregation and wage differentials in a competitive market, as people try to minimize inter-group communication. $\mathrm{He}$ further asserts that minority language knowledge may act as a mark for economic discrimination and lower earnings as it identifies to employers differences and deep affiliation with an ethnic or cultural community and identity.

Hellerstein and Neumark $(2002,2005,2008)$ emphasize the advantages of employer-employee linked data to study labour market discrimination, since most discriminatory workplace policies and practices occur at the establishment level. In addition to providing tests of discrimination, matched employer-employee data have proven useful in measuring labour market 
segregation and assessing its consequences. Their empirical results show considerable segregation by Hispanic ethnicity and by English language proficiency. Hispanic workers, but not white workers, suffer wage penalties from employment in a workplace with a large share of Hispanic workers, and even more so with a large share of Hispanic workers with poor English.

Using matched employee-employer data from the 1999 WES, Drolet (2002) demonstrates that the inclusion of workplace characteristics and practices and more accurate industry measures dramatically increases the 'explained' component of gender wage gap to nearly 60 per cent. Almost 43 per cent of the pay gap can be explained by workplace characteristics. Workplace practices alone (including receipt of performance-based pay, participation in self-directed workgroups, overtime pay, training expenditures per employee, workplace part-time rate) explain 23.5 per cent of the male-female pay gap.

In total, these studies show how various individual and workplace characteristics, including the concentration of immigrants, whether minority status is visible and the use of minority language can have an influence on gender or ethnic wage differentials. However, information about workplace characteristics and practices is typically not available in the census data or major household survey data in Canada, such as the Labour Market Activity Survey or the Survey of Labour and Income Dynamics.

\section{The Interaction of Gender and Minority Differentials}

Past work on the relationship between performance pay and minority wage differentials has not placed emphasis on the role of gender. The examination by Heywood and O'Halloran for the United States examines only males. The earlier Canadian examination by Fang and Heywood combines the genders and presents only a single parsimonious estimate that divides the sample by gender. This lack of emphasis should be reconsidered, given the substantial evidence that North American minority wage differentials differ dramatically by gender. This was noted by Cain (1986) and remains pronounced with Bayard et al. (1999) putting the US black-white wage differential for men at $-0.121 \log$ wages for men but at only $-0.022 \log$ wages for women. Among the hypotheses suggested to explain this larger difference are differences in the intensity of prejudice, differences in the degree of labour force attachment, with minority women having greater attachment relative to nonminority women than do minority men relative to non-minority men, and that the degree of ethnic segregation is far smaller among women than among men (see Bayard et al. 1999; Hellerstein and Neumark 2008).

The presence of such contrasting ethnic wage differences by gender suggests that patterns associated with performance pay for men or for the entire workforce may not hold for women. In particular, if the minority wage differential is already small or near zero for women, the difference between performance pay and time rates may be anticipated to make little or no difference. 


\section{Data and variables}

We draw data from the 1999 Canadian WES. The WES is linked data consisting of both employer and employee components. Employers are sampled by physical location, and employees are then sampled within each location. The survey excludes business locations in the Yukon, Nunavut and the Northwest Territories, as well as agriculture, fishing, road, bridge and highway maintenance, government services, and religious organizations. The initial wave of the WES was first conducted during the summer and fall of 1999. Responses were received from 6,322 business locations and 23,540 employees, with response rates as high as 95.2 per cent for employers and 82.8 per cent for employees.

The survey contains detailed demographic and labour market information on individual workers, and also information on workplace characteristics, business strategy and human resource practices. It allows us to identify whether respondents are immigrants and of what vintage. It identifies whether the respondent uses a foreign language (a language other than English or French) as their primary language at home, and also identifies the respondent's ethnic background. Following previous evidence from Canada, we break down the simple immigration dummies to indicate the decade (1970s, 1980s or 1990s) in which the immigrant arrived. ${ }^{3}$ Our expectation is that more recent immigrants will tend to have lower earnings. Recent immigrants may be more likely to lack skills and abilities specific to the Canadian labour market, as they acquire these skills over time. Alternatively, the most recent cohort may have lower earnings potential compared with earlier cohorts. Nonetheless, both recent immigrant status and use of a foreign language at home stand, in part, as measures of human capital that should be held constant so as to isolate the true influence of ethnicity.

The WES also includes information on education, actual reported full-time years of experience, employee union/collective bargaining agreement coverage, marital status, whether or not the worker has received training (either on-the-job or classroom) over the last year, and workplace size. With rich regional and industry controls, the WES allows testing the hypothesis that payment methods influence ethnic wage differentials after accounting for immigration and language. Note that we largely focus the examination on the non-union sector. This decision follows from Fang and Heywood (2006), and recognizes the small extent of performance pay in the union sector and our inability to identify a return to performance pay in the union sector.

The earnings data indicate whether or not they originate from wages or salary, piece rates, tips, commissions, profit sharing or bonuses. As with many data sources, the actual amounts of earnings attributable to these sources are not available, but it is common for workers receiving output pay to also receive a base time rate. In identifying output pay, we begin with a broad definition that includes piece rates, tips, commissions and bonuses. We follow that with a narrower definition suggested by Parent (1999) and Heywood and O'Halloran (2005) that combines piece rates, tips and 
commissions into a single measure, but recognizes bonuses as a more discretionary form of payment and includes it in the base with time rates. In a third step, this narrow definition of performance pay requires us to think about the appropriate set of occupations upon which to perform our estimations. Output pay is concentrated among sales, technical and production workers, and is less common among managers, professionals and clerical workers. ${ }^{4}$ Despite a substantial loss in sample size, we limit the sample to the first three occupational groups in our third set of estimations. ${ }^{5}$

In our analysis, we use a single combined 'Non-European' indicator to identify workers whose parents or grandparents did not descend from one or more of four ethnic groups: (i) Canadian, (ii) British, (iii) French, and (iv) other European. Thus, we combine the more than one dozen categories for Blacks, Chinese, Southeast Asians, Natives and other non-Europeans into a singe category in an attempt to strike a balance between detailed ethnic indicators and a reasonable sample size for the minority group. We do, however, discuss robustness checks that suggest our findings are not driven by any single ethnic minority. Unfortunately, we do not have workplace level data on ethnic composition, but we recognize that such data could be used to more directly investigate issues of segregation and dominate individual measures of ethnicity.

The wages of workers reported as other than hourly are converted into an hourly rate based on total compensation and total hours of work. This convention allows inclusion of those paid on a salary basis. Reflecting the survey design, we make no assumptions about particular observations being outliers and do not trim the dataset. Whenever reported earnings are above or below cut-offs determined by an imputation process, the survey managers directly confirmed the earnings data with the respondent. ${ }^{6}$

The descriptive statistics by payment method are presented in Table 1 and a more complete breakdown by both gender and payment method is presented in Appendix Table A1. A full list of detailed variable definitions is available upon request from the authors. The mean wages in Table 1 show that among our Canadian non-union sample using the broader definition of output pay (bonus included), the mean wages of those on output pay are 25.8 per cent more (\$20.62 vs \$16.39). At the same time, non-Europeans earn 3.5 per cent less than Europeans ( $\$ 17.24$ vs $\$ 17.84$ ). When divided by sector, non-European workers earn more on average when receiving output pay ( $\$ 21.04$ vs $\$ 15.41$ ), while Europeans also earn more but the gap is not as large (\$20.55 vs $\$ 16.55$ ). Put differently, on average, non-Europeans earn 2.4 per cent more than European Canadians when receiving output pay, but 7.4 per cent less than European Canadians when paid time rates. These raw averages hint at lower or even positive ethnic earnings differentials in the performance pay sector, but obviously they do not adjust for other relevant earnings determinants. Table A1 provides the descriptive statistics divided by both gender and the receipt of output pay.

To determine the impact of payment methods, immigration status and minority language on potential ethnic wage differentials, we estimate wage 
TABLE 1

Weighted Means by Payment Scheme (Based on Non-Union Sample and the Broad Definition of Output Pay)

\begin{tabular}{|c|c|c|c|c|}
\hline Variable & $\begin{array}{l}\text { Output pay } \\
\text { (means) }\end{array}$ & $\begin{array}{l}\text { Output pay } \\
\text { (s.d.) }\end{array}$ & $\begin{array}{c}\text { Time rate } \\
\text { (means) }\end{array}$ & $\begin{array}{c}\text { Time rate } \\
\text { (s.d.) }\end{array}$ \\
\hline Hourly wage & 20.62 & 13.58 & 16.39 & 9.94 \\
\hline (Non-immigrants and immigrants who arrived before 1970s) & 0.867 & 0.340 & 0.866 & 0.341 \\
\hline Immigrants who arrived in the 1970 s & 0.052 & 0.223 & 0.043 & 0.204 \\
\hline Immigrants who arrived in the $1980 \mathrm{~s}$ & 0.045 & 0.208 & 0.044 & 0.205 \\
\hline Immigrants who arrived in the $1990 \mathrm{~s}$ & 0.035 & 0.184 & 0.046 & 0.211 \\
\hline Non-Europeans & 0.136 & 0.343 & 0.144 & 0.352 \\
\hline Foreign language at home & 0.071 & 0.257 & 0.083 & 0.276 \\
\hline Female & 0.512 & 0.500 & 0.539 & 0.499 \\
\hline Age in years & 37.83 & 10.51 & 39.27 & 11.65 \\
\hline Married ( 1 if married, 0 otherwise) & 0.590 & 0.492 & 0.546 & 0.498 \\
\hline Years of education & 13.94 & 2.27 & 13.58 & 2.42 \\
\hline Dependent children & 0.437 & 0.496 & 0.418 & 0.493 \\
\hline Presence of young children & 0.202 & 0.402 & 0.181 & 0.385 \\
\hline Part time & 0.113 & 0.316 & 0.167 & 0.373 \\
\hline Supervision (supervision of other employees' work on a day-to-day basis) & 0.481 & 0.500 & 0.405 & 0.491 \\
\hline Member of a team ( 1 if yes, 0 if no) & 0.567 & 0.496 & 0.424 & 0.494 \\
\hline Years of experience & 15.50 & 10.13 & 15.76 & 10.96 \\
\hline Job tenure in years & 7.45 & 7.45 & 6.93 & 7.26 \\
\hline Months of unemployment in the past five years & 1.09 & 3.80 & 1.44 & 4.87 \\
\hline Working at home (hours worked at home in a usual week) & 1.82 & 4.48 & 1.40 & 4.14 \\
\hline Training received ( 1 if yes, 0 if no) & 0.603 & 0.489 & 0.492 & 0.500 \\
\hline Workplace size (log of total establishment employment) & 3.79 & 1.72 & 3.56 & 1.90 \\
\hline Observations & 5,607 & 5,607 & 10,699 & 10,699 \\
\hline
\end{tabular}

Notes: Output pay includes piece rates, commissions, tips and bonuses. Also included are dummy variables identifying 6 occupations, 6 regions and 14 industries.

Means are available from the authors. s.d. = standard deviation. 
functions from various sub-samples of the WES. We use survey regression methods and employee survey weights provided by the WES identifying the primary survey units as the establishments from which multiple workers may be interviewed. ${ }^{7}$ The resulting estimation is designed to return representative results and to provide heteroskedasticity-robust standard errors. These errors correct for the common components associated with a cluster of workers from a given workplace (for more on when to use heteroskedasticityrobust standard errors, see Stock and Watson 2003: 596-7).

\section{Results}

Table 2 shows earnings equations estimated separately within the samples of ethnic minorities and of non-minorities. These estimates make a series of points that begin our inquiry. First, among ethnic minorities in Canada, women do not seem disadvantaged in our base estimate that controls for performance pay. This result persists even when performance pay is removed as a control. Second, the estimates support the point from past research that the influence of performance pay is larger among ethnic minorities. Further, the addition of the immigration and language variables influences the ethnic minorities more than the non-minorities, as would be expected, but they do not change either the return to performance pay or the estimated gender differentials. It remains the case that among nonminorities, women suffer a double-digit percentage wage penalty, but that among minorities, the penalty is very small and insignificantly different from zero. Among the minorities, recent immigrants and those using a foreign language at home earn less.

With these points taken, we now examine the core question of how the ethnic earnings gap varies between those receiving output pay and those receiving time rates. Table 3 summarizes the results and shows that among women receiving time rates, there exists no ethnic earnings gap. Thus, the earlier finding that the ethnic earnings gap exists in the time rate sector but not the performance pay sector is not driven by women but exclusively by men. Among men, ethnic minorities suffer significantly lower earnings, 0.14 $\log$ wages lower, than non-minorities. Adding the immigration and language controls appears associated with a decline in this differential, but it remains statistically significant.

These results can be contrasted with those in the output pay sector (again using the broadest definition) as shown in Table 3. The initial estimates in columns 1 and 3 show neither gender with a significant ethnic differential, and the results broadly mirror those presented by Fang and Heywood (2006). Again, the controls for immigration and language add little to the male estimations. Among women, the immigration and language controls emerge as important, with both being associated with reduced earnings. The fact that the most recent immigrant cohort is strongly associated with reduced earnings could reflect either that immigrants assimilate over time and the penalty 
TABLE 2

Estimated Gender Wage Gap and Return to Output Pay (Broad Definition) by Ethnicity: Based on Non-Union Sample

\begin{tabular}{|c|c|c|c|c|c|c|}
\hline & \multicolumn{3}{|c|}{ Non-Europeans } & \multicolumn{3}{|c|}{ Europeans } \\
\hline & 1 & 2 & 3 & 4 & 5 & 6 \\
\hline Female & $-0.017(-0.51)$ & $-0.035(-1.09)$ & $-0.037(-1.16)$ & $-0.129^{* * *}(-7.97)$ & $-0.130^{* * *}(-8.03)$ & $-0.130^{* * *}(-8.05)$ \\
\hline $\begin{array}{l}\text { Output pay } \\
\text { (Non-immigrants or immigrants who } \\
\text { arrived before } 1970 \mathrm{~s} \text { ) }\end{array}$ & $0.157^{* * *}(4.76)$ & $0.147^{* * *}(4.52)$ & $0.152^{* * *}(4.79)$ & $0.115^{* * *}(7.25)$ & $0.115^{* * *}(7.22)$ & $0.116^{* * *}(7.26)$ \\
\hline Immigrants who arrived in the 1970 s & & $-0.015(-0.37)$ & $0.0005(0.01)$ & & $0.058(1.59)$ & $0.054(1.47)$ \\
\hline Immigrants who arrived in the 1980 s & & $-0.085^{* *}(-2.09)$ & $-0.045(-1.08)$ & & $-0.051(-0.97)$ & $-0.060(-1.13)$ \\
\hline Immigrants who arrived in the $1990 \mathrm{~s}$ & & $-0.197 * * *(-4.88)$ & $-0.153^{* * *}(-3.65)$ & & $-0.015(-0.24)$ & $-0.034(-0.54)$ \\
\hline Foreign language at home & & & $-0.080^{* *}(-2.31)$ & & & $-0.044(-1.05)$ \\
\hline Observations & 1,982 & 1,982 & 1,982 & 14,324 & 14,324 & 14,324 \\
\hline$R^{2}$ & 0.562 & 0.579 & 0.583 & 0.533 & 0.533 & 0.533 \\
\hline
\end{tabular}

Notes: Models also include occupations (six categories), regions (six categories), and industries (14 categories). Absolute values of $t$-statistics based on robust standard errors are in parentheses.

* Significant at $10 \% ; * *$ significant at $5 \% ; * * *$ significant at $1 \%$. 
TABLE 3

Estimated Ethnic Wage Gap by Output Pay (Broad Definition) and by Gender: Based on the Non-Union Sample

\begin{tabular}{|c|c|c|c|c|c|c|c|c|}
\hline & \multicolumn{4}{|c|}{ Output pay } & \multicolumn{4}{|c|}{ Time rates } \\
\hline & \multicolumn{2}{|c|}{ Men } & \multicolumn{2}{|c|}{ Women } & \multicolumn{2}{|c|}{ Men } & \multicolumn{2}{|c|}{ Women } \\
\hline & 1 & 2 & 3 & 4 & 5 & 6 & 7 & 8 \\
\hline $\begin{array}{l}\text { Non-Europeans } \\
\text { (Non-immigrants or } \\
\text { immigrants who arrived } \\
\text { before 1970s) }\end{array}$ & $-0.028(-0.61)$ & $-0.012(-0.30)$ & $0.020(0.47)$ & $0.128^{* * *}(2.68)$ & $-0.140^{* * *}(-3.44)$ & $-0.091^{* *}(-2.20)$ & $-0.031(-0.99)$ & $-0.004(-0.09)$ \\
\hline Immigrants in the 1970s & & $0.057(1.08)$ & & $-0.045(-0.79)$ & & $0.082(1.64)$ & & $0.047(0.92)$ \\
\hline Immigrants in the $1980 \mathrm{~s}$ & & $-0.070(-0.89)$ & & $-0.032(-0.49)$ & & $-0.043(-0.70)$ & & $-0.006(-0.11)$ \\
\hline Immigrants in the 1990s & & $-0.073(-1.34)$ & & $-0.171^{* *}(-2.21)$ & & $0.009(0.16)$ & & $-0.219^{* * *}(-4.04)$ \\
\hline Foreign language & & $0.021(0.40)$ & & $-0.169 * * *(-2.81)$ & & $-0.053(-1.28)$ & & $0.035(0.81)$ \\
\hline Age & $0.050^{* * *}(5.22)$ & $0.051^{* * *}(5.20)$ & $0.048 * * *(4.55)$ & $0.048 * * *(4.66)$ & $0.027^{* * *}(3.84)$ & $0.027^{* * * *}(3.88)$ & $0.022^{* * *}(3.64)$ & $0.023^{* * * *}(3.80)$ \\
\hline Age squared & $-0.001^{* * *}(-5.23)$ & $-0.001^{* * *}(-5.28)$ & $-0.001 * * *(-4.41)$ & $-0.001^{* * *}(4.50)$ & $-0.0003^{* * *}(-3.85)$ & $-0.0003^{* * *}(-3.91)$ & $-0.0003 * * *(-3.59)$ & $-0.0002^{* * * *}(-3.74)$ \\
\hline Married & $0.033(1.12)$ & $0.034(1.13)$ & $0.098^{* * *}(2.85)$ & $0.111(3.22)$ & $0.075^{* * *}(2.82)$ & $0.077^{* * *}(2.91)$ & $0.076^{* * *}(3.38)$ & $0.080^{* * *}(3.58)$ \\
\hline Years of education & $0.019^{* *}(2.49)$ & $0.019 * *(2.52)$ & $0.045^{* * *}(5.00)$ & $0.046^{* * *}(5.15)$ & $0.028^{* * *}(5.46)$ & $0.028^{* * *}(5.45)$ & $0.029 * * *(5.75)$ & $0.029 * * *(5.86)$ \\
\hline Years of experience & $0.003(0.92)$ & $0.003(0.83)$ & $0.008 * *(2.67)$ & $0.007^{* *}(2.43)$ & $0.006 * * *(2.91)$ & $0.006^{* * *}(2.81)$ & $0.002^{* *}(2.08)$ & $0.002^{*}(1.95)$ \\
\hline Job tenure & $0.007 * * *(3.27)$ & $0.007^{* * *}(3.27)$ & $0.004(1.30)$ & $0.003(1.23)$ & $0.006^{* * *}(3.43)$ & $0.006^{* * *}(3.38)$ & $0.011^{* * *}(7.29)$ & $0.011^{* * *}(6.81)$ \\
\hline Supervisor & $0.090^{* * *}(3.31)$ & $0.092^{* * *}(3.39)$ & $0.042(1.12)$ & $0.039(1.06)$ & $0.072^{* * *}(2.94)$ & $0.072^{* * *}(2.93)$ & $0.017(0.082)$ & $0.018(0.86)$ \\
\hline Workplace size & $0.071^{* * *}(6.87)$ & $0.071^{* * *}(6.87)$ & $0.035^{* * *}(3.27)$ & $0.036^{* * * *}(3.31)$ & $0.050^{* * *}(6.89)$ & $0.050^{* * *}(6.86)$ & $0.043^{* * *}(8.06)$ & $0.044^{* * *}(8.12)$ \\
\hline Months unemployed & $-0.006^{*}(-1.81)$ & $-0.007 *(-1.83)$ & $0.003(1.01)$ & $0.004(1.39)$ & $-0.005^{* *}(-1.97)$ & $-0.005^{* *}(-2.02)$ & $-0.002(-0.96)$ & $-0.003(-1.17)$ \\
\hline Work hours at home & $0.007^{*}(1.66)$ & $0.007^{*}(1.69)$ & $0.011^{* *}(2.49)$ & $0.011^{* * *}(2.69)$ & $0.005(1.34)$ & $0.005(1.36)$ & $0.006^{*}(1.70)$ & $0.006(1.61)$ \\
\hline Training received & $0.021(0.65)$ & $0.020(0.65)$ & $0.086^{* * *}(2.84)$ & $0.085^{* * *}(2.81)$ & $0.045^{*}(1.89)$ & $0.044 *(1.85)$ & $0.017(0.86)$ & $0.020(1.00)$ \\
\hline Dependent children & $-0.025(-0.57)$ & $-0.024(-0.54)$ & $-0.137^{* * *}(-3.14)$ & $-0.134 * * *(-3.13)$ & $0.024(0.75)$ & $0.025(0.80)$ & $-0.041(-1.50)$ & $-0.041(-1.52)$ \\
\hline Young children & $0.037(0.99)$ & $0.038(1.02)$ & $0.058(1.27)$ & $0.061(1.35)$ & $0.074^{* *}(1.97)$ & $0.073^{*}(1.95)$ & $0.083^{* * *}(2.81)$ & $0.087^{* * * *}(3.00)$ \\
\hline Part time & $-0.011(-0.14)$ & $-0.011(-0.13)$ & $0.093^{* *}(2.03)$ & $0.094^{* *}(2.05)$ & $-0.0005(-0.01)$ & $-0.002(-0.05)$ & $0.053^{* *}(2.05)$ & $0.048^{*}(1.89)$ \\
\hline Constant & $1.531^{* * *}(7.05)$ & $1.516^{* * * *}(6.88)$ & $1.197^{* * *}(5.49)$ & $1.156 * * *(5.39)$ & $1.649 * * *(9.35)$ & $1.633^{* * *}(9.12)$ & $1.807^{* * *}(12.57)$ & $1.787(12.60)$ \\
\hline$R^{2}$ & 0.511 & 0.512 & 0.532 & 0.542 & 0.471 & 0.473 & 0.513 & 0.520 \\
\hline$N$ & 3,247 & 3,247 & 2,360 & 2,360 & 5,714 & 5,714 & 4,985 & 4,985 \\
\hline
\end{tabular}

Notes: Models also include occupations (six categories), regions (six categories), and industries (14 categories). Absolute values of $t$-statistics based on robust standard errors are in parentheses.
* Significant at 10\%; ${ }^{* *}$ significant at $5 \%$; $* * *$ significant at $1 \%$. 
vanishes, or that the recent cohort is of lower productivity. In our crosssectional data, we cannot distinguish between these two interpretations. Importantly, the high correlation between ethnicity and the immigration and language variables alters the estimated ethnic wage differential. In the final estimation in column 4, minority women earn significantly more than nonminority women.

At least from the point of view of internal consistency, this paradoxical result for women might have been expected. We saw earlier that among minorities, there was no gender wage differential (Table 2). Moreover, we saw that minorities earned more from being on output pay than did nonminorities. Thus, holding constant the strong associations between minority status and immigration, and between minority status and language, we observe minority women on output pay earning more than non-minority women. One possibility is that there is stronger positive selection by minority women than non-minority women into jobs paying output-related pay. Those minority women with the greatest ability (much of it unmeasured in our variables) may be more likely to enter the performance pay sector. As an illustration, it might be that their lack of detailed cultural knowledge is less of a detriment in this sector than would be true for men. Alternatively, this gender difference may reflect detailed gender segregation by jobs that we are not capturing.

To explore the robustness of our findings, we repeat the exercise with the narrower definition of performance pay that classifies bonuses as part of the base. The point estimates change, but the pattern established in Table 3 does not. As Table 4 shows, only men paid time rates emerge with a negative ethnic earnings differential, as minority and non-minority women on time rates earn essentially the same. The initial estimates in columns 1 and 3 of Table 4 show neither gender with a significant ethnicity differential among those receiving the narrow definition of output pay. Again, it is women on output pay that seem to be most influenced by immigration and language indicators, and after holding these constant, there continues to be evidence that among women receiving output pay, minorities earn more.

Finally, we limit our sample to those three broad occupations in which workers are most likely to encounter both time rates and output pay. As Table 5 shows, the initial evidence before adding the immigration and language controls looks similar with a negative earnings differential for minority men on time rates but not for those in the performance pay sector. The addition of the immigration and language variables again indicate a significant positive coefficient for minority women in the output sector. The notable difference within this sample is for the men on time rates. The inclusion of the language and immigration variables causes the male minority differential to vanish for the first time. Thus, in this narrow sample, we find no evidence in either sector that ethnic minorities in Canada are underpaid given their immigration status and language usage. There remains evidence that language and immigration status are determinants of earnings, and while 
TABLE 4

Estimated Ethnic Wage Gap by Output Pay (Narrow Definition) and by Gender: Based on the Non-Union Sample

\begin{tabular}{|c|c|c|c|c|c|c|c|c|}
\hline & \multicolumn{4}{|c|}{ Output pay } & \multicolumn{4}{|c|}{ Time rates } \\
\hline & \multicolumn{2}{|c|}{ Men } & \multicolumn{2}{|c|}{ Women } & \multicolumn{2}{|c|}{ Men } & \multicolumn{2}{|c|}{ Women } \\
\hline & 1 & 2 & 3 & 4 & 5 & 6 & 7 & 8 \\
\hline $\begin{array}{l}\text { Non-Europeans } \\
\text { (Non-immigrants or } \\
\text { immigrants who } \\
\text { arrived before } \\
\text { 1970s) }\end{array}$ & $0.046(0.67)$ & $0.083(0.85)$ & $-0.059(-0.44)$ & $0.282^{* *}(2.19)$ & $-0.090^{* * *}(-3.18)$ & $-0.069 * *(-2.12)$ & $-0.012(-0.44)$ & $0.017(0.51)$ \\
\hline $\begin{array}{l}\text { Immigrants who } \\
\text { arrived in the } \\
1970 \text { s }\end{array}$ & & $-0.168(-1.61)$ & & $-0.385^{* *}(-2.56)$ & & $0.071 *(1.75)$ & & $0.051(1.36)$ \\
\hline $\begin{array}{l}\text { Immigrants who } \\
\text { arrived in the } \\
\text { 1980s }\end{array}$ & & $-0.052(-0.45)$ & & $-0.185(-1.55)$ & & $-0.050(-0.91)$ & & $-0.015(-0.31)$ \\
\hline $\begin{array}{l}\text { Immigrants who } \\
\text { arrived in the } \\
1990 \text { s }\end{array}$ & & $0.044(0.36)$ & & $-0.356^{*}(-1.84)$ & & $-0.039(-0.87)$ & & $-0.201 * * *(-4.04)$ \\
\hline $\begin{array}{l}\text { Foreign language } \\
\text { at home }\end{array}$ & & $-0.032(-0.35)$ & & $-0.342^{* *}(-2.01)$ & & $-0.030(-0.75)$ & & $0.009(0.21)$ \\
\hline$R^{2}$ & 638 & 638 & 468 & 468 & 8,323 & 8,323 & 6,877 & 6,877 \\
\hline$N$ & 0.632 & 0.635 & 0.507 & 0.544 & 0.490 & 0.492 & 0.522 & 0.527 \\
\hline
\end{tabular}

Notes: Models have included occupations (six categories), regions (six categories), industries (14 categories) and all other explanatory variables shown in Table 3. $t$-statistics based on robust standard errors are in parentheses.

${ }^{*}$-statignificant at $10 \% ; * *$ significant at $5 \% ; * * *$ significant at $1 \%$. 
TABLE 5

Estimated Ethnic Wage Gap by Output Pay (Narrow Definition) and by Gender: Based on Limited Non-Union Sample

\begin{tabular}{|c|c|c|c|c|c|c|c|c|}
\hline & \multicolumn{4}{|c|}{ Output pay } & \multicolumn{4}{|c|}{ Time rates } \\
\hline & \multicolumn{2}{|c|}{ Men } & \multicolumn{2}{|c|}{ Women } & \multicolumn{2}{|c|}{ Men } & \multicolumn{2}{|c|}{ Women } \\
\hline & $I$ & 2 & 3 & 4 & 5 & 6 & 7 & 8 \\
\hline $\begin{array}{l}\text { Non-Europeans } \\
\text { (Non-immigrants or } \\
\text { immigrants who } \\
\text { arrived before } \\
1970 \text { s) }\end{array}$ & $0.056(0.73)$ & $-0.015(-0.16)$ & $0.045(0.31)$ & $0.345^{* *}(2.10)$ & $-0.062^{*}(-1.67)$ & $0.004(0.08)$ & $-0.059(-1.51)$ & $-0.015(-0.35)$ \\
\hline $\begin{array}{l}\text { Immigrants who } \\
\text { arrived in the } \\
1970 \mathrm{~s}\end{array}$ & & $-0.203(-1.49)$ & & $-0.200(-1.02)$ & & $0.010(0.17)$ & & $0.043(0.68)$ \\
\hline $\begin{array}{l}\text { Immigrants who } \\
\text { arrived in the } \\
\text { 1980s }\end{array}$ & & $0.135(0.83)$ & & $-0.128(-0.74)$ & & $-0.071(-0.86)$ & & $0.020(0.27)$ \\
\hline $\begin{array}{l}\text { Immigrants who } \\
\text { arrived in the } \\
1990 \text { s }\end{array}$ & & $0.206(1.25)$ & & $0.058(0.19)$ & & $0.046(0.64)$ & & $-0.215^{* * *}(-3.12)$ \\
\hline $\begin{array}{l}\text { Foreign language } \\
\text { at home }\end{array}$ & & $0.023(0.17)$ & & $-0.501^{* * *}(-2.41)$ & & $-0.162^{* * *}(-2.97)$ & & $-0.016(-0.31)$ \\
\hline$R^{2}$ & 0.640 & 0.646 & 0.495 & 0.532 & 0.400 & 0.408 & 0.409 & 0.419 \\
\hline$N$ & 318 & 318 & 238 & 238 & 3,485 & 3,485 & 2,144 & 2,144 \\
\hline
\end{tabular}

Notes: Models have included occupations (three categories), regions (six categories), industries (14 categories) and all other explanatory variables shown in

Table 3. $t$-statistics based on robust standard errors are in parentheses.

* Significant at $10 \% ;{ }^{* *}$ significant at $5 \% ;{ }^{* * *}$ significant at $1 \%$. 
broadly consistent with evidence that there is convergence between the earnings of immigrants and non-immigrants over time, our data does not allow us to confirm this.

\section{Robustness Checks}

We have undertaken a series of robustness checks that largely reinforce the findings shown. While we do not present tables of results for all of these, we emphasize that they are available from the authors. First, we divided the ethnic minority variable into four categories: black, Asian, native and other non-European. In the regression equivalents to columns 5-8 in Table 4, the coefficients on both Asian and other non-Europeans emerge as negative and significant for males in the time rate sector, but not for women. In the equivalent of Table 5 , there are no significant coefficients.

Given the relatively high simple correlations between immigration status, ethnicity and foreign language use, the influence of multi-collinearity on the estimates in columns 2, 4,6 and 8 is an obvious concern. As a diagnostic tool, we calculate the variance inflation factors (VIFs) for each of the critical variables. The VIFs identify how much the variance of the coefficient estimate is being inflated by multi-collinearity. Specifically, the square root of the VIFs is how much larger the standard error is when compared with what it would be if the variable was uncorrelated with the other regressors in the equation (see Allison 1999). We calculated VIFs for many of the specifications, and the largest VIFs among the ethnicity, language and immigration variables reached only 2.2 for foreign language. Values this low generally suggest that multi-collinearity is not obscuring general patterns (a typical rule-of-thumb for severe multi-collinearity requires VIFs of 10 or greater).

There may be differences both in the occupations in the two sectors and in the extent of gender sorting. We calculated gender segregation indices separately for the time rate and output pay sectors across the 24 underlying occupational classifications within our already limited sample. The indices identify the share of workers of one gender that would need to change occupations in order to create identical distributions across occupations for men and women. In the time rate sector, the index takes a value of 54.0, while in the output pay sector it is only 41.0. Thus, the gender distribution of occupations is more nearly similar in the output pay sector. This results because of more similar concentrations in wholesale, technical and real estate sales and in several of the trade occupations. ${ }^{8}$

We have largely limited our investigation to the non-union sector due to the relative absence of both performance pay and a performance pay influence on earnings in the unionized sector. Nonetheless, there may be interest in the earnings differentials by minority, language and gender status in the unionized sector given the preponderance of time rates. In specifications that mimic the more complete specification in Table 3, we find no significant wage differential associated with non-European minorities for either men or women in either the output pay or time rate sectors. Foreign language is 
associated with significantly lower earnings for both genders in the output pay sector, and immigration status emerges with one or more significant negative coefficients for both genders in the time rate sector and for men in the output pay sector.

We recognize the fact that we have multiple observations from some establishments (although because there remain more than 4,000 $(4,259)$ underlying establishments, many do not have multiple observations). This allows us to control for fixed effects for the establishment in those cases in which multiple observations exist, and re-estimate the regressions in an unbalanced panel. These results do not substantially alter the patterns we have shown. In reproducing Tables 3, 4 and 5, each shows a significant positive coefficient for non-European women in the output pay sector. Moreover, estimates for the broader sample (shown in Table 6 and analogous to Table 4) indicate a significant negative coefficient for non-European males in time rates. In unreported fixed effects estimates of the complete specification using the narrow sample (analogous to Table 5), the pattern in Table 5 of no significant differences for non-European males in either sector is replicated. Thus, although there are necessary differences in coefficients and levels of significance, the broad pattern we outline is replicated.

Finally, while our discussion has implicitly recognized that the choice of sector may be endogenous, we have not attempted to model that process. The underlying choice structure includes a firm choice to offer output pay, the worker choice to seek employment at such an employer and the employer's decision to hire particular workers among those seeking employment in their sector. While this structure may make it difficult to find suitable instruments, it is worth thinking a minute about the worker choice aspect. If there are unmeasured factors (such as ability) that are associated both with earnings and worker choice of sector, it is possible that returns to output pay will be biased. Moreover, if the nature of those factors differs between European and non-European workers, it is conceivable that the differences we identify by sector and minority status are also misleading. We necessarily leave this for future work.

\section{Conclusions}

This article explores the sensitivity of measures of ethnic earnings differentials to separate estimation by gender and to the inclusion of controls for immigration and foreign language use. This exploration modifies what is known about the relationship between output pay and minority earnings differentials in Canada. There appears to be no gender earnings differentials among ethnic minorities. Related to this, there is no evidence of a negative ethnic earnings differential among women in either the time rate or output pay rate. Indeed, after accounting for immigration and language, the evidence is that female ethnic minorities earn more than non-minority women in the output pay sector. We speculate this may reflect greater positive selection by minority women, but this remains only a hypothesis. 
TABLE 6

Fixed-effects Estimates of Ethnic Wage Gap by Output Pay (Narrow Definition) and by Gender: Based on Non-Union Sample

\begin{tabular}{|c|c|c|c|c|}
\hline & \multicolumn{2}{|c|}{ Output pay } & \multicolumn{2}{|c|}{ Time rates } \\
\hline & $\begin{array}{c}\text { Men } \\
1\end{array}$ & $\begin{array}{l}\text { Women } \\
\quad 2\end{array}$ & $\begin{array}{c}\text { Men } \\
3\end{array}$ & $\begin{array}{l}\text { Women } \\
\quad 4\end{array}$ \\
\hline $\begin{array}{l}\text { Non-Europeans } \\
\text { (Non-immigrants or immigrants who arrived before } 1970 \text { s) }\end{array}$ & $-0.014(-0.07)$ & $0.369 *(1.90)$ & $-0.057^{* *}(-2.79)$ & $-0.011(-0.52)$ \\
\hline & $0.216(0.64)$ & $-0.136(-0.48)$ & $0.064^{* *}(2.30)$ & $-0.022(-0.84)$ \\
\hline Immigrants who arrived in the $1980 \mathrm{~s}$ & $-0.150(-0.52)$ & $-0.226(-0.71)$ & $-0.009(-0.29)$ & $-0.047(-1.49)$ \\
\hline & $-0.332(-0.81)$ & $-0.004(-0.01)$ & $-0.038(-1.13)$ & $-0.148^{* * *}(-4.01)$ \\
\hline$R^{2}$ Foreign language at home & $0.257(0.90)$ & $0.135(0.44)$ & $-0.018(-0.69)$ & $0.009(0.34)$ \\
\hline $\begin{array}{l}R^{2} \\
N\end{array}$ & 638 & 468 & 8,323 & 6,877 \\
\hline & 0.112 & 0.160 & 0.363 & 0.315 \\
\hline
\end{tabular}

standard errors are included occupations (six categories), and all other explanatory variables shown in Table 2. Absolute values of $t$-statistics based on robust * Significant at $10 \%$;* significant at $5 \% ; * * *$ significant at $1 \%$. 
Thus, the earlier result in the literature that performance pay is associated with reducing the ethnic wage differential to near zero even as it remains negative in the time rate sector does not apply to women. Even the time-rate differential for women appears to be near zero. The difference between time rates and performance pay does appear to apply to men in our early estimates. Minority men suffer double-digit earnings differentials in the time rate sector that accounting for language and immigration reduce but do not eliminate. They suffer no significant earnings differential in the output pay sector. Yet when we examine the narrow sample designed to limit ourselves to the broad occupations in which choices between time rate and performance pay seem more likely, a different pattern emerges. The significant negative differential faced by minority men in the time rate sector is eliminated by the inclusion of language and immigration controls. This confirms the suspected role played by these variables and suggests that the high correlation between immigration, language and minority status must be accounted for when estimating ethnic wage differences.

Final version accepted on 12 February 2009.

\section{Acknowledgements}

The authors wish to thank three reviewers, Alex Bryson and the participants at the British Journal of Industrial Relations Workshop on 'The Political Economy of Immigration and Migration Labour' for valuable comments, Lucy Chung and Yves Decady at Statistics Canada for exceptional data support, and the Social Science and Humanities Research Council of Canada for financial support.

\section{Notes}

1. As an illustration, the automotive products marketing firm Ashland Canada Ltd. dismissed a commissioned sales worker for 'poor performance' but was forced to make restitution and pay a fine when it was revealed that the employee routinely exceeded the company set sales goals (Dessler et al. 2005).

2. The authors emphasize that between their examination and the earlier examination by Bronars and Moore (1995), the NLSY cohort had aged, and that high-ability non-whites (as measured by AFQT scores) became increasingly concentrated in the output pay sector. Moreover, they replicate the Bronars and Moore findings using the earlier data, but the exact model applied to the later data, suggesting that the change in results reflects a change in the labour market, not in modelling.

3. There are relatively few immigrants prior to 1970 , and we varied their treatment with no substantive change in results. We excluded them from the estimations, put them in a residual category of 'other immigrants', and simply included them in the base. The estimations shown reflect the last treatment, but we emphasize that the choice is immaterial. 
4. About 9.1 per cent of workers in the first three occupational groups report output pay, while only 4.7 per cent of workers in the latter three occupations report output pay. Interestingly, within the latter three occupations, those reporting output pay are concentrated among managers. This seems the least comparable occupational group, as managers directly monitor the performance of other workers and are typically removed from a suitable individual measure of productivity. What they identify as output pay may more nearly resemble executive compensation.

5. By limiting ourselves to these occupations, we examine a set of workers who are likely to actually face a choice of whether or not to work for an employer with output pay. Second, we reduce the unmeasured differences in workers and jobs that could drive spurious results, as earnings regimes (beyond occupation shift parameters) may differ across broad occupational groups. Finally, we also reduce the risk that estimations undertaken on the full sample merely reflect occupational sorting. Thus, the occupational groups in which output pay is prevalent may simply have reduced earnings dispersion, including reduced ethnic wage differentials. Thus, what we would attribute to output pay in the full sample could actually be attributable to unmeasured occupational differences.

6. Indeed, the data maximum and minimum seem believable with the absolute smallest wage being nearly four dollars an hour, and the highest just above 120 dollars an hour.

7. All estimations are done in Stata 8 using the 'survey' commands and identifying the underlying establishments as the primary survey units. This automatically generates robust standard errors while the survey weights return consistent point estimates.

8. To the extent that gender segregation reflects a desire for flexible jobs (Bender $e t$ al. 2005), those women willing to trade off earnings for flexibility are more likely to be observed in the time rate sector. Thus, as a possibility, the output pay sector may disproportionately reflect women motivated by high earnings.

\section{References}

Allison, D. A. (1999). Multiple Regression: A Primer. Thousand Oaks, CA: Sage Publications.

Baker, G., Gibbons, R. and Murphy, K. (1994). 'Subjective performance measures in optimal incentive contracts'. Quarterly Journal of Economics, 109 (November): $1125-56$.

Bayard, K., Hellerstein, J., Neumark, D. and Troske, K. R. (1999). 'Why Are Racial and Ethnic Wage Gaps Larger for Men than for Women? Exploring the Role of Segregation'. NBER Working Paper No. 6997.

Becker, G. S. (1971). The Economics of Discrimination, 2nd edn. Chicago and London: The University of Chicago Press.

Belman, D. and Heywood, J. S. (1988). 'Incentive schemes and racial wage discrimination'. Review of Black Political Economy, 17: 47-56.

Bender, K. A., Donohue, S. and Heywood, J. S. (2005). 'Job satisfaction and gender segregation'. Oxford Economic Papers, 57: 479-96.

Bloom, D. E., Grenier, G. and Gunderson, M. (1995). 'The changing labour market position of Canadian immigrants'. Canadian Journal of Economics, 28: 987-1005. 
Bronars, S. G. and Moore, C. (1995). 'Incentive Pay, Information, and Earnings: Evidence from the NLSY'. US Department of Labor, Bureau of Labor Statistics, Discussion Paper, Report: NLS 95-23.

Cain, G. (1986). 'The economic analysis of labor market discrimination: a survey'. In O. Ashenfelter and R. Layard (eds.), Handbook of Labor Economics, Vol. 1. Amsterdam: North-Holland.

Chiswick, B. R. (1991). 'Speaking, reading, and earnings among low-skilled immigrants'. Journal of Labor Economics, 9: 149-70.

- (1992). Immigration, Language, and Ethnicity: Canada and the United States. Washington, DC: The American Enterprise Institute Press.

Christofides, L. and Swidinsky, R. (1997). Bilingualism and Earnings: A Study Based on 1971, 1981 and 1991 Census Data. Ottawa: Official Languages Branch, Dept of Canadian Heritage.

Conference Board of Canada (2004). 'The voices of visible minorities: speaking out on breaking down barriers'. September 2004 Briefing.

Davila, A., Bohara, A. K. and Saenz, R. (1993). 'Accent penalties and the earnings of Mexican Americans'. Social Science Quarterly, 74: 902-16.

Dessler, G., Cole, N. and Sutherland, V. (2005). Human Resource Management in Canada, 9th edn. Toronto: Pearson, Prentice-Hall.

Drolet, M. (2002). 'New evidence on gender pay differentials: does measurement matter?' Canadian Public Policy, 28: 41-63.

Dustmann, C. (1994). 'Speaking fluency, writing fluency and earnings of migrants'. Journal of Population Economics, 7: 133-56.

Elvira, M. and Town, R. (2001). 'The effects of race and worker productivity on performance evaluations'. Industrial Relations, 40: 571-90.

Fang, T. and Heywood, J. (2006). 'Output pay and ethnic wage differentials: Canadian evidence'. Industrial Relations, 45: 173-94.

Geddes, L. and Heywood, J. S. (2003). 'Gender and piece rates, commissions and bonuses'. Industrial Relations, 42: 419-44.

Gunderson, M. (1975). 'Male-female wage differentials and the impact of equal pay legislation'. Review of Economics and Statistics, 57: 462-69.

Hellerstein, J. K. and Neumark, D. (2002). 'Ethnicity, Language, and Workplace Segregation: Evidence from a New Matched Employer-Employee Data Set'. NBER Working Papers 9037, Cambridge, MA: National Bureau of Economic Research.

__ and - (2005). 'Using Matched Employer-Employee Data to Study Labor Market Discrimination'. IZA Discussion Papers 1555, Institute for the Study of Labor (IZA).

— and - (2008). 'Workplace segregation in the United States: race, ethnicity and skill'. Review of Economics and Statistics, 90: 459-77.

Heywood, J. S. and O'Halloran, P. L. (2005). 'Racial earnings differentials and performance pay'. Journal of Human Resources, 40: 435-52.

Jirjahn, U. and Stephan, G. (2004). 'Gender, piece rates and wages: evidence from matched employer-employee data'. Cambridge Journal of Economics, 28: 683-704.

Kossoudji, S. A. (1988). 'English language ability and the labor market opportunities of Hispanic and East Asian immigrant men'. Journal of Labor Economics, 6: 20528.

Lang, K. (1986). 'A language theory of discrimination'. Quarterly Journal of Economics, 101: 363-82. 
- (1993). 'Language and economists' theories of discrimination'. International Journal of the Sociology of Language, 103: 165-83.

Lazear, E. P. (1986). 'Salaries and piece rates'. Journal of Business, 59: 405-31.

(1995). 'Culture and Language'. NBER Working Paper No. 5249, Cambridge, MA: National Bureau of Economic Research.

Parent, D. (1999). 'Methods of pay and earnings: a longitudinal analysis'. Industrial and Labor Relations Review, 53: 71-86.

Pendakur, K. and Pendakur, R. (1998). 'The colour of money: income differentials across ethnic groups'. Canadian Journal of Economics, 31: 518-48.

- and - (2002). 'Speaking in tongues: language knowledge as human capital and ethnicity'. International Migration Review, 36: 147-78.

Prendergast, C. and Topel, R. (1996). 'Favoritism in organizations'. Journal of Political Economy, 104: 958-78.

Statistics Canada (2003a). 'Ethnic diversity survey: portrait of a multicultural society'. Catalogue No. 89-593-XIE.

- (2003b). 'Ethnocultural Portrait of Canada, 2001 Census'. Catalogue No. 97F0004XCB2001000.

Stock, J. H. and Watson, M. W. (2003). Introduction to Econometrics. Boston, MA: Pearson Educational Publishing.

Stolzenberg, R. M. and Tienda, M. (1997). 'English proficiency, education, and the conditional economic assimilation of Hispanic and Asian origin men'. Social Science Research, 26: 25-51.

Tienda, M. and Neidert, L. (1984). 'Language, education, and the socioeconomic achievement of Hispanic origin men'. Social Science Quarterly, 65: 519-36. 


\section{Appendix}

TABLE A1

Weighted Means by Payment Scheme and Gender (Based on Non-Union Sample and the Broad Definition of Output Pay)

\begin{tabular}{|c|c|c|c|c|}
\hline Variable & Output pay (men) & Output pay (women) & Time rate (men) & Time rate (women) \\
\hline Hourly wage & $24.30(15.34)$ & $17.10(10.52)$ & $18.31(10.68)$ & $14.75(8.95)$ \\
\hline (Non-immigrants and immigrants who arrived before 1970s) & $0.870(0.336)$ & $0.864(0.343)$ & $0.854(0.353)$ & $0.876(0.329)$ \\
\hline Immigrants who arrived in the 1970 s & $0.039(0.193)$ & $0.065(0.247)$ & $0.041(0.199)$ & $0.045(0.207)$ \\
\hline Immigrants who arrived in the 1980 s & $0.054(0.227)$ & $0.037(0.189)$ & $0.049(0.216)$ & $0.040(0.195)$ \\
\hline Immigrants who arrived in the $1990 \mathrm{~s}$ & $0.037(0.188)$ & $0.034(0.180)$ & $0.055(0.228)$ & $0.039(0.194)$ \\
\hline Non-Europeans & $0.142(0.350)$ & $0.130(0.336)$ & $0.153(0.360)$ & $0.137(0.344)$ \\
\hline Foreign language at home & $0.076(0.265)$ & $0.066(0.249)$ & $0.085(0.278)$ & $0.082(0.274)$ \\
\hline Age in years & $38.25(10.39)$ & $37.34(10.60)$ & $39.55(11.69)$ & $39.04(11.62)$ \\
\hline Married ( 1 if married, 0 otherwise) & $0.639(0.480)$ & $0.542(0.498)$ & $0.567(0.496)$ & $0.529(0.499)$ \\
\hline Years of education & $14.05(2.50)$ & $13.84(2.01)$ & $13.48(2.55)$ & $13.66(2.30)$ \\
\hline Dependent children & $0.463(0.499)$ & $0.411(0.492)$ & $0.437(0.496)$ & $0.402(0.490)$ \\
\hline Presence of young children & $0.239(0.427)$ & $0.166(0.373)$ & $0.206(0.404)$ & $0.159(0.366)$ \\
\hline Part time & $0.061(0.240)$ & $0.161(0.368)$ & $0.083(0.276)$ & $0.238(0.426)$ \\
\hline Supervision (supervision of other employees' work on a day-to-day basis) & $0.587(0.492)$ & $0.380(0.486)$ & $0.492(0.498)$ & $0.331(0.471)$ \\
\hline Member of a team ( 1 if yes, 0 if no) & $0.648(0.478)$ & $0.490(0.500)$ & $0.460(0.498)$ & $0.394(0.489)$ \\
\hline Years of experience & $17.21(10.42)$ & $14.44(9.65)$ & $17.46(11.54)$ & $14.31(10.22)$ \\
\hline Job tenure in years & $8.29(8.05)$ & $6.65(6.73)$ & $7.28(7.85)$ & $6.63(6.71)$ \\
\hline Months of unemployment in the past five years & $1.03(3.60)$ & $1.15(3.97)$ & $1.47(4.91)$ & $1.40(4.83)$ \\
\hline Working at home (hours worked at home in a usual week) & $2.51(5.24)$ & $1.17(3.49)$ & $1.51(4.38)$ & $1.30(3.91)$ \\
\hline Training received ( 1 if yes, 0 if no) & $0.628(0.483)$ & $0.580(0.494)$ & $0.476(0.499)$ & $0.506(0.500)$ \\
\hline Workplace size (log of total establishment employment) & $3.99(1.72)$ & $3.60(1.70)$ & $3.60(1.83)$ & $3.53(1.97)$ \\
\hline Observations & 3,247 & 2,360 & 5,714 & 4,985 \\
\hline
\end{tabular}

Notes: Output pay includes piece rates, commissions, tips and bonuses. Also included are dummy variables identifying 6 occupations, 6 regions and 14 industries.

Standard deviations of the means are in parentheses. 